\title{
Viral Hepatitis Prevalence in Two Cognitively Different Risk Groups
}

\author{
Bilișsel Olarak Farklı Iki Risk Grubunda Viral Hepatit Sıklğı
}

\author{
๑ Gülden Eser Karlıdağำ ๑ Kürşat Karadaban²
}

${ }^{1}$ Elazığ Fethi Sekin City Hospital, Clinic of Infectious Diseases and Clinical Microbiology, Elazığ, Turkey

2Elazığ Kovancılar State Hospital, Clinic of Infectious Diseases and Clinical Microbiology, Elazı̆̆, Turkey

\begin{abstract}
Objectives: This study aimed to investigate whether patient awareness of viral hepatitis affected the prevalence of the condition by comparing the awareness levels in two high-risk groups with different cognitive abilities.

Materials and Methods: Hepatitis B surface antigen ( $\mathrm{HBsAg}$ ), anti-HBs, anti-HAV immunoglobulin G (lgG), anti-HCV and Human Immunodeficiency Virus (HIV) seropositivity values of healthcare workers (HCWs) working in a state hospital and of individuals treated in a State Care and Rehabilitation Center for the Mentally Disabled (SCRCMD) between January 1, 2016 and December 31, 2018 were analyzed retrospectively.

Results: One hundred and two HCWs and 110 individuals followedup by the SCRCMD were included in the study. Of the HCWs, two (2\%) were HBsAg positive, 93 (91.2\%) were anti-HBs positive and $85(83.3 \%)$ were anti-HAV lgG positive. None of the HCWs were anti-HCV or HIV positive. Of the individuals followed-up by the SCRCMD, eight (7.3\%) were HBsAg positive, 61 (55.5\%) were anti-HBs positive, 95 (86.4\%) were anti-HAV IgG positive and one $(0.9 \%)$ was anti-HCV positive. None of the individuals followed-up by the SCRCMD were HIV positive. Anti-HBs positivity was found significantly lower in the SCRCMD group compared to the HCW group ( $p<0.001$ ).
\end{abstract}

Conclusion: Effective infection control measures and more frequent vaccination may reduce hepatitis infection rates in risk groups, especially among individuals with lower cognitive awareness.

Keywords: Hepatitis, seroprevalence, cognitive status, risk group öz

Amaç: Bu çalışma ile viral hepatitler için yüksek risk grubunda olan fakat bilişsel olarak farkı iki grup arasındaki hastalık farkındalığının hastalık sıklı̆ını etkileyip etkilemediğinin araştırıması amaçlandı.

Gereç ve Yöntemler: Kamuya bağlı devlet hastanesi sağlık çalışanları ile yine kamuya bağlı Ruhsal Engelli Bakım ve Rehabilitasyon Merkezi'nde (REBRM) yaşayan bireylerin 1 Ocak 2016 - 31 Aralık 2018 tarihleri arasındaki hepatit B yüzey antijeni (HBsAg), antiHBs, anti-HAV immünoglobulin G (lgG), anti-HCV, HIV seropozitiflik durumları retrospektif olarak incelendi.

Bulgular: Çalışmaya 102 sağlık çalışanı ve REBRM'de takip edilen 110 birey dahil edildi. Sağlık çalışanlarının ikisinde (\%2) HBsAg pozitif, 93'ünde $(\% 91,2)$ anti-HBs pozitif ve 85 'inde $(\% 83,3)$ antiHAV IgG pozitifliği saptanırken, hiçbir sağlık çalışanında anti-HCV ve HIV pozitifliği saptanmadı. REBRM'de takip edilen bireylerin 8'inde $(\% 7,3) \mathrm{HBsAg}$ pozitif, 61 'inde $(\% 55,5)$ anti-HBs pozitif, 95'inde $(\% 86,4)$ anti-HAV IgG pozitif ve birinde $(\% 0,9)$ ise anti-HCV pozitifliği saptandı. REBRM bireylerin hiçbirinde HIV pozitifliği saptanmadı. Sağlık çalışanlarına göre REBRM'deki bireylerde anti-HBs pozitifliği anlamlı olarak düşük saptandı $(p<0,001)$.

Sonuç: Risk gruplarında özellikle de bilişsel olarak farkındalığı daha düşük bireylerde enfeksiyon kontrol önlemlerinin daha etkin uygulanması ve aşılama oranlarının artırıması, hepatit enfeksiyon oranlarını azaltılabilir.

Anahtar Kelimeler: Hepatit, seroprevalans, bilişsel durum, risk grubu

Eser Karlıdağ G, Karadaban K. Viral Hepatitis Prevalence in Two Cognitively Different Risk Groups. Viral Hepat J. 2019;25:79-83.

Address for Correspondence: Gülden Eser Karlıdağ MD, Elazığ Fethi Sekin City Hospital, Clinic of Infectious Diseases and Clinical Microbiology, Elazı̆̆, Turkey Phone: +905359487408 E-mail: guldeneser@gmail.com ORCID: orcid.org/0000-0002-0754-1702 Received: 10.04.2019 Accepted: 28.07.2019

${ }^{\circ}$ Copyright 2019 by Viral Hepatitis Society / Viral Hepatitis Journal published by Galenos Publishing House. 


\section{Introduction}

Globally, about 240 million people are reported to be affected by chronic Hepatitis B Virus (HBV) infection and 185 million people by Hepatitis $C$ Virus $(H C V)$ infection $(1,2)$. Despite the recent global decrease in the prevalence of Hepatitis $B$, according to a recent analysis the rate of deaths from liver complications associated with hepatitis B has increased by 33\% from 1990 to 2013, (3). $\mathrm{HCV}$ infection is a major public health problem globally. To be able to establish evidence-based health policies and to wisely use the resources, it is vital to know the epidemiology of $\mathrm{HCV}$ infection and its disease burden (4). HBV and HCV is transmitted by infected blood and other body fluids, and acquired through parenteral, sexual, horizontal, nosocomial and perinatal contact $(2,5)$. In Turkey, the prevalence of HBV infection is reported to be $4 \%$ and of $\mathrm{HCV}$ infection $1 \%$, with variations among regions (6).

Healthcare workers (HCWs) are exposed to numerous infectious agents because of their profession. Individuals working in the operation room, the intensive care unit, the laboratories and the emergency room are in contact with infected patient materials such as blood and other body fluids, which causes them to be more frequently exposed to agents transmitting blood-borne diseases. According to data of the World Health Organization (WHO), more than 85 million people working in hospitals worldwide are injured by contaminated medical instruments (7). Evidence shows that mentally disabled persons are at higher risk of Human Immunodeficiency Virus (HIV), Hepatitis B and Hepatitis $\mathrm{C}$ infections than the general population. These patients have less knowledge about how infectious diseases are acquired and which protective measures should be taken. Moreover, they may engage in risky sexual behaviors, and maintain below-average life and hygiene standards. These may constitute the factors that increase transmission risk among mentally disabled individuals (8).

As previous studies report higher rates for the eastern regions of Turkey compared to the western regions, in this study we aimed to investigate whether awareness of patients in an eastern region of Turkey had an effect on the prevalence of the viral hepatitis and compared the awareness levels of two high-risk groups with different cognitive abilities.

\section{Materials and Methods}

The study was conducted in the eastern city of Elazığ and included HCWs from the state district hospital and individuals staying in a State Care and Rehabilitation Center for the Mentally Disabled (SCRCMD). Approval was obtained from the Ethics Committee of Firat University for the study (approval number: 03/20, date: 07.02.2019). The study was designed in line with the Ethical Principles for Medical Research Involving Human Subjects set forth by the World Medical Association in the Declaration of Helsinki.

Hepatitis B surface antigen ( $\mathrm{HBsAg})$, anti-HBs, anti-hepatitis A virus (HAV)-immunoglobulin G (lgG), anti-HCV and HIV seropositivity data of the patients recorded from 1 January 2016 to 31 December 2018 were retrospectively examined. Patients with a recurrent condition were excluded. HBsAg, Anti-HBs, antiHAV-lgG, anti-HCV and HIV serological values were tested using the Chemiluminescent Microparticle Immunoassay method on an Architect i2000 SR (Abbott, USA) device. In the HCV-positive patients, HCV-RNA levels were measured by real time Polymerase chain reaction using Rotor-Gene $\mathrm{Q}$ analyser (Qiagene, Hilden, Germany). HBsAg positive patients were divided into two groups, the chronic infection group and the chronic hepatitis group, based on their HBV-DNA levels, HBeAg positivity/negativity, ALT levels, and liver histology, as recommended in the EASL 2017 guidelines (9). Follow-up and treatment processes of the patients were planned as recommended in EASL 2017 guidelines.

\section{Statistical Analysis}

The data were analyzed using the SPSS 22.0 package program. The Pearson chi-square test was used for inter-group variables, and a $p<0.05$ value was considered as the limit of significance.

\section{Results}

Of the $102 \mathrm{HCW}$ included in the study 56 (54.9\%) were male and $46(45.09 \%)$ were female, with an age range from 21 to 53 (mean: $33.96 \pm 8.53$ years). All 110 individuals in the SCRCMD group were male with an age range from 20 to 71 (mean: 50.60 11.04 years). The HCWs group included 41 (40.1\%) nurses-midwives, $16(15.6 \%)$ doctors, $16(15.6 \%)$ health technicians (anesthesia technician, health officer), 14 (13.7\%) laboratory technicians, 12 (11.7\%) cleaning personnel, and $3(2.9 \%)$ ambulance drivers.

Two (2\%) of the HCWs were HBsAg positive, 93 (91.2\%) were anti-HBs-positive, and 85 (83.3\%) were anti-HAV-lgG positive, however, none were anti-HCV or HIV-positive. One of the two HCWs diagnosed with chronic Hepatitis B was a nurse and the other a cleaning personnel. No statistically significant differences were identified between HBsAg and anti-HAV-lgG positivity based on occupation groups; however, anti-HBs positivity was found to be significantly lower in the cleaning personnel compared to the other HCWs ( $p=0.002$ ) (Table 1).

Of the individuals in the SCRCMD group, 8 (7.3\%) were HBsAgpositive, 61 (55.5\%) were anti-HBs-positive, 95 (86.4\%) were antiHAV-lgG-positive, and 1 (0.9\%) was anti-HCV positive. None was identified to be HIV positive. Comparison of the HCWs group and the SCRCMD group showed no statistically significant differences for HBsAg, anti-HAV-lgG and anti-HCV positivity, but significantly lower anti-HBs positivity in the SCRCMD group $(p<0.001)$ (Table 1).

Of the two HBsAg-positive individuals in the HCWs group, one was receiving treatment with oral antivirals for chronic hepatitis and had negative HBV-DNA, and the other was monitored for chronic infection. Of the eight HBsAg positive individuals in the SCRCMD group, one was receiving antiviral treatment and had negative HBV-DNA. Evaluation of laboratory values showed chronic infection in four patients and follow-up processes were planned. Three patients were evaluated to have chronic hepatitis and started on oral antivirals. One anti-HCV positive patient had previously received treatment and had negative HCV-RNA.

\section{Discussion}

In our study, anti-HBs positivity was identified as $91.2 \%$ in the HCWs group and $55.5 \%$ in the SCRCMD group. The lowest anti-HBs positivity level in the HCWs group was identified in the cleaning personnel (53.1\%). Seropositivity rates of the groups are seen to be in line with the education and awareness levels of the individuals. 


\begin{tabular}{|c|c|c|c|c|c|c|}
\hline & & \multicolumn{5}{|c|}{ Seropositivity } \\
\hline & & HBsAg & Anti-HBs & Anti-HCV & Anti-HAV-IgG & Anti-HIV \\
\hline \multirow{14}{*}{$\begin{array}{l}\text { Healthcare workers } \\
\text { (HCWs) }(n=102)\end{array}$} & \multirow{2}{*}{$\begin{array}{l}\text { Doctors } \\
(n=16)\end{array}$} & 0 & 15 & 0 & 14 & 0 \\
\hline & & $0 \%$ & $93.8 \%$ & $0 \%$ & $87.5 \%$ & $0 \%$ \\
\hline & \multirow{2}{*}{$\begin{array}{l}\text { Nursing } \\
(\mathrm{n}=41)\end{array}$} & 1 & 39 & 0 & 32 & 0 \\
\hline & & $2.4 \%$ & $95.1 \%$ & $0 \%$ & $78.0 \%$ & $0 \%$ \\
\hline & \multirow[t]{2}{*}{ Laboratory technicians $(n=14)$} & 0 & 13 & 0 & 11 & 0 \\
\hline & & $0 \%$ & $92.9 \%$ & $0 \%$ & $78.6 \%$ & $0 \%$ \\
\hline & \multirow{2}{*}{ Health technicians $(n=16)$} & 0 & 16 & 0 & 15 & 0 \\
\hline & & $0 \%$ & $100 \%$ & $0 \%$ & $93.8 \%$ & $0 \%$ \\
\hline & \multirow{2}{*}{ Cleaning personnel $(n=12)$} & 1 & 7 & 0 & 11 & 0 \\
\hline & & $8.3 \%$ & $58.3 \%$ & $0 \%$ & $91.7 \%$ & $0 \%$ \\
\hline & \multirow{2}{*}{ Ambulance drivers $(n=3)$} & 0 & 3 & 0 & 2 & 0 \\
\hline & & $0 \%$ & $100 \%$ & $0 \%$ & $66.7 \%$ & $0 \%$ \\
\hline & \multirow{2}{*}{ Total } & 2 & 93 & 0 & 85 & 0 \\
\hline & & $2 \%$ & $91.2 \%$ & $0 \%$ & $83.3 \%$ & $0 \%$ \\
\hline \multirow{2}{*}{ SCRCMD (n=110) } & & 8 & 61 & 1 & 95 & 0 \\
\hline & & $7.3 \%$ & $55.5 \%$ & $0.9 \%$ & $86.4 \%$ & $0 \%$ \\
\hline
\end{tabular}

In 1992 WHO and International Labor Organization have acknowledged HBV as an occupational disease factor (10). In 1996, the Turkish Ministry of Health initiated a practice requiring the examination and, if necessary, the vaccination of $\mathrm{HCW}$ s against this virus (11). A study carried out by the European Centre for Disease Prevention and Control in European countries, reported the lowest rate for HBsAg positivity among the general population in the Netherlands and Ireland (0.1\%), and the highest in Turkey (9\%). The same study reported the lowest rate for anti-HCV positivity in Belgium $(0.1 \%)$ and the highest in Italy (22.4\%) (12).

$\mathrm{HBV}$ infection in HCWs occurs by contact with blood rather than by contact with the patients. Supporting HCWs, in particular, not only are in direct contact with patients but often come into contact with infected blood and other similar materials (13). Although lumen needles are often held responsible for documented HCV infection events, such infection can be transmitted via blood splash into conjunctiva or lumenless needles. Despite such risks, the prevalence of $\mathrm{HCV}$ infection among $\mathrm{HCW}$ s is not higher than that of the general population. Only $1-2 \%$ of all needle accidents experienced by the HCWs are reported to be caused by needles used in HCV-infected patients (14). Recent studies have shown that HCV infection could be eliminated in 15-20 years through diagnosis, treatment and strategies toward preventing new cases. To be able to develop the strategies that will eliminate HCV infection, however, it is important to clearly understand the epidemiology of the disease $(15,16)$.

As is the case across the world, improvement in hygiene and sanitation conditions leads to progress in socio-economic conditions, and decrease in HAV circulation among children, as well as an increase in the number of sensitive adults, and the slow progression of the disease in advanced ages (17). Hepatitis
A prevalence is closely related to the indicators of socio-economic development levels, particularly to geographical differences, hygiene and other health conditions (18). Turkey has intermediate endemicity with data showing a prevalence of 8-88\%. Increase in the mean age for exposure to the virus has raised the number of adolescents and adults who are mindful of the condition in areas of intermediate endemicity (19).

A study conducted in South Korea with $571 \mathrm{HCWs}$, reported HBsAg positivity to be $2.4 \%$ and anti-HBs positivity $76.9 \%$, and that these rates were not different from that of the general

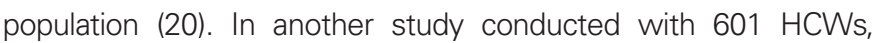
HBsAg positivity was found $1.8 \%$, and anti-HBs positivity $51.4 \%$; and anti-HBs positivity was identified in laboratory technicians $(63.6 \%)$, doctors $(62.7 \%)$, nurses $(52 \%)$ and cleaning personnel (40\%) (21).

In a study conducted in Turkey with HCWs, HBsAg positivity of $5.8 \%$ was identified among $14.000 \mathrm{HCWs}$ in the years from 1980 to 1990 , and of $3.6 \%$ from 1990 to 2000; and this decrease was found statistically significant (22). HBsAg and anti-HBs positivity among HCWs in Turkey, one of the risk groups for Hepatitis B infection, was reported $3 \%$ and $78.3 \%$ by Demir et al. (23); $2.3 \%$ and $68.8 \%$ by Kutlu et al. (24); $1.28 \%$ and $88.3 \%$ by Uludağ Altun et al. (25); and $0.5 \%$ and $88.28 \%$ by Keçik Boşnak et al. (11). Korkmaz et al. (26), on the other hand, reported HBsAg positivity to be $0.9 \%$, anti-HBs positivity $86 \%$ and found the lowest antiHBs positivity values among the cleaning personnel. Another study reported $\mathrm{HBsAg}$ positivity to be $1 \%$ and anti-HBs positivity $62.7 \%$. This study reported the highest anti-HBs positivity values in doctors (95\%) and the lowest anti-HBs positivity values in cleaning personnel (43.86\%) (22). In our study, HBsAg positivity among $\mathrm{HCW}$ s was found $2 \%$ and anti-HBs positivity $91.2 \%$. 
The highest anti-HBs positivity was found among nurses (95.3\%) and the lowest among cleaning personnel (53.1\%). These rates are comparable to the results reported in the literature. That the lowest anti-HBs rate among HCWs was identified in the cleaning personnel may be associated with education and awareness.

In a study conducted with $\mathrm{HCW}$ s of five hospitals in the same country, anti-HCV positivity was found to be $2 \%$ (21). Anti-HCV positivity among HCWs in Turkey is reported to range from $0 \%$ to $0.34 \%(11,22,25,26)$. Similarly, no anti-HCV and HIV positivity was identified among HCWs in our study.

Kurugol et al. (27) report anti-HAV-lgG positivity among the by general population in Turkey to be $85.83 \%$ for the $20-29$ age group, $95.6 \%$ for the $30-39$ age group, and $99 \%$ for the +40 -age group. Korkmaz et al. (26) found an anti-HAV-lgG positivity rate of $71.7 \%$ among HCWs. In our study, we identified anti-HAV-IgG positivity in 85 out of $102 \mathrm{HCWs}$ (83.3\%). WHO recommends Hepatitis A vaccination in regions of intermediate endemicity, where the number of mindful adults with a severely progressing disease is seen to increase parallel to the improvements in sanitation conditions (18). In our study, vaccination was recommended to HCWs who were identified to be seronegative for Hepatitis A.

A study, in which 5.227 mentally disabled individuals were evaluated, HBsAg positivity was reported to be $4.08 \%$, anti-HBs positivity $42.19 \%$, anti-HCV positivity $0.69 \%$, while no anti-HIV positivity was identified (28). In our study, HBsAg positivity was found $7.3 \%$, anti-HBs positivity $55.5 \%$, anti-HCV positivity $0.9 \%$ in the SCRCMD group. HIV positivity was not identified. Although proportional difference was found in HBsAg positivity between the HCWs group and in the SCRCMD group, this difference was not statistically significant. This may be a result of the small number of our sample size. We believe that studies with larger-scale samples are needed. No statistically significant differences were identified in anti-HBs positivity between the two groups $(p=0.000)$.

\section{Study Limitations}

The limitation of our study was the low number of cases and reflecting local data.

\section{Conclusion}

To conclude, that anti-HBs positivity was found lower for the cleaning personnel, individuals possibly of lower educational levels compared to other HCWs, and in the SCRCMD group, emphasizes the importance of differences in cognitive abilities an aspect we have considered when planning and designing our study. Individuals that fall in risk groups should be carefully examined for seropositivity and non-immune individuals should be included in Hepatitis B and Hepatitis A vaccination programs. We believe that hepatitis infection rates can be reduced in risk groups, especially among individuals with lower cognitive awareness, through more effective infection control measures and more frequent vaccination.

\section{Ethics}

Ethics Committee Approval: Approval was obtained from the Ethics Committee of Firat University for the study (approval number: 03/20, date: 07.02.2019).

Informed Consent: Retrospective study.

Peer-review: Externally peer-reviewed.

\section{Authorship Contributions}

Medical Practices: G.E.K., Concept: G.E.K., Design: G.E.K., Data Collection or Processing: G.E.K., K.K., Analysis or Interpretation: G.E.K., K.K, Literature Search: G.E.K., Writing: G.E.K., K.K.

Conflict of Interest: The authors declare no conflict of interest.

Financial Disclosure: The authors declare that this study has not received any financial support.

\section{References}

1. Schweitzer A, Horn J, Mikolajczyk RT, Krause G, Ott JJ. Estimations of worldwide prevalence of chronic hepatitis $B$ virus infection: $A$ systematic review of data published between 1965 and 2013. Lancet 2015;386:1546-1555.

2. Alter MJ. Epidemiology of hepatitis C. Hepatology. 1997;26:62-65.

3. Stanaway JD, Flaxman $A D$, Naghavi $M$, Fitzmaurice $C$, Vos T, Abubakar I, Abu-Raddad LJ, Assadi R, Bhala N, Cowie B, Forouzanfour $\mathrm{MH}$, Groeger J, Hanafiah $\mathrm{KM}$, Jacobsen $\mathrm{KH}$, James SL, MacLachlan J, Malekzadeh R, Martin NK, Mokdad AA, Mokdad AH, Murray CJL, Plass D, Rana S, Rein DB, Richardus JH, Sanabria J, Saylan M, Shahraz S, So S, Vlassov VV, Weiderpass E, Wiersma ST, Younis M, Yu C, El Sayed Zaki M, Cooke GS. The global burden of viral hepatitis from 1990 to 2013: findings from the Global Burden of Disease Study 2013. Lancet. 2016;388:1081-1088

4. Mohd Hanafiah K, Groeger J, Flaxman AD, Wiersma ST. Global epidemiology of hepatitis $C$ virus infection: new estimates of age-specific antibody to HCV seroprevalence. Hepatology. 2013:57:1333-1342.

5. Hou J, Liu Z, Gu F. Epidemiology and prevention of hepatitis B virus infection. Int J Med Sci. 2005;2:50-57.

6. Tozun N, Ozdogan O, Cakaloglu Y, Idilman R, Karasu Z, Akarca U, Kaymakoglu S, Ergonul O. Seroprevalance of hepatitis B and C virus infections and risk factors in Turkey: a fieldwork TURHEP study. Clin Microbiol Infect. 2015;21:1020-1026.

7. Prüss-Ustün A, Rapiti E, Hutin Y. Estimation of the global burden of disease attributable to contaminated sharps injuries among health-care workers. Am J Ind Med. 2005;48:482-490.

8. Kakisi OK, Grammatikos AA, Karageorgopoulos DE, Athanasoulia AP, Papadopoulou AV, Falagas ME. Prevalence of hepatitis B, hepatitis $\mathrm{C}$, and HIV infections among patients in a psychiatric hospital in Greece. Psychiatr Serv. 2009;60:1269-1272.

9. European Association for the Study of the Liver. Electronic address: easloffice@easloffice.eu; European Association for the Study of the Liver. EASL 2017 clinical practice guidelines on the management of hepatitis B virus infection. J Hepatol. 2017:67:370-398

10. Immunization of health-care workers: recommendations of the Advisory Committee on Immunization Practices (ACIP) and the Hospital Infection Control Practices Advisory Committee (HICPAC). MMWR Recomm Rep. 1997; 46:1-42.

11. Keçik Boșnak V, Karaoğlan I, Namıduru M, Sahin A. Seroprevalences of Hepatitis B, Hepatitis C, HIV of the Healthcare Workers in the Gaziantep University Sahinbey Research and Training Hospital. Viral Hepatitis Journal. 2013;19:11-14.

12. European Centre for Disease Prevention and Control. Hepatitis $B$ and $C$ in the EU neighbourhood: prevalence, burden of disease and screening policies. Stockholm: ECDC; 2010. Available from: http://www.ecdc.europa.eu/en/publications/Publications/ TER_100914_Hep_B_C\%20_EU_neighbourhood.pdf.

13. Karslıgil T, Uygur O. Evoluation of HBV antibodies evoked by immunization and infection among health employee and population. Eur J Ther 2007;13:31-34. 
14. Ray SC, Thomas DL. Hepatitis C. In: Mandell GL, Bennett JE, Dolin R, eds. Mandell, Douglas, and Bennett's Principles and Practice of Infectious Diseases. 8th ed. Philadelphia, PA: Churchill Livingstone Elsevier, 2015:1904-1927.

15. Gower E, Estes C, Blach S, Razavi-Shearer K, Razavi H. Global epidemiology and genotype distribution of the hepatitis $\mathrm{C}$ virus infection. J Hepatol. 2014;61:45-57.

16. Wedemeyer $H$, Duberg AS, Buti M, Rosenberg WM, Frankova S, Esmat G, Örmeci N, Van Vlierberghe H, Gschwantler $M$, Akarca U, Aleman S, Balık I, Berg T, Bihl F, Bilodeau M, Blasco AJ, Brandão Mello CE, Bruggmann P, Calinas F, Calleja JL, Cheinquer $H$, Christensen PB, Clausen M, Coelho HS, Cornberg M, Cramp ME, Dore GJ, Doss W, El-Sayed MH, Ergör G, Estes C, Falconer K, Félix J, Ferraz ML, Ferreira PR, García-Samaniego J, Gerstoft J, Giria JA, Gonçales FL Jr, Guimarães Pessôa M, Hézode C, Hindman SJ, Hofer $H$, Husa P, Idilman R, Kåberg M, Kaita KD, Kautz A, Kaymakoglu S, Krajden M, Krarup H, Laleman W, Lavanchy D, Lázaro P, Marinho RT, Marotta P, Mauss S, Mendes Correa MC, Moreno C, Müllhaupt B, Myers RP, Nemecek V, Øvrehus AL, Parkes J, Peltekian KM, Ramji A, Razavi H, Reis N, Roberts SK, Roudot-Thoraval F, Ryder SD, Sarmento-Castro R, Sarrazin C, Semela D, Sherman M, Shiha GE, Sperl J, Stärkel P, Stauber RE, Thompson AJ, Urbanek P, Van Damme P, van Thiel I, Vandijck D, Vogel W, Waked I, Weis N, Wiegand J, Yosry A, Zekry A, Negro F, Sievert W, Gower E. Strategies to manage hepatitis C virus (HCV) disease burden. J Viral Hepat. 2014; 21:60-89.

17. Franco E, Meleleo C, Serino L, Sorbara D, Zaratti L. Hepatitis A: Epidemiology and prevention in developing countries. World $\mathrm{J}$ Hepatol. 2012; 4:68-73.

18. Jacobsen $\mathrm{KH}$, Wiersma ST. Hepatitis A virus seroprevalence by age and world region, 1990 and 2005. Vaccine. 2010; 28:66536657.
19. Yoldaş Ö, Bulut A, Altındiş M. The current approach of hepatitis A infections. Viral Hepatitis Journal. 2012;18:81-86.

20. Shin BM, Yoo HM, Lee AS, Park SK. Seroprevalence of hepatitis $B$ virus among health care workers in Korea. J Korean Med Sci. 2006;21:58-62.

21. Elzouki AN, Elgamay SM, Zorgani A, Elahmer O. Hepatitis B and C status among health care workers in the five main hospitals in eastern Libya. J Infect Public Health. 2014;7:534-541.

22. Inci M, Aksebzeci AT, Yağmur G, Kartal B, Emiroğlu M, Erdem Y. Investigation of HBV, HCV and HIV seropositivity in healthcare workers. Turk Hij Den Biyol Derg. 2009;66:59-66.

23. Demir I, Kaya S, Demirci M, Cicioğlu-Arıdoğan B. Investigation of seropositivity of hepatitis B virus in healthcare workers in Isparta, Türkiye. Turkish Journal of Infection. 2006;20:183-187.

24. Kutlu R, Demirbaş N. Serum HbsAg and anti-Hbs levels with hepatitis B vaccination status in hospital staff admitted for health screening. TJFMPC. 2016;10:136-141.

25. Uludağ Altun H, Eraslan A, Özdemir G. Seroprevalences of HBV, HCV and HIV among healthcare workers in a secondary care hospital. Viral Hepatitis Journal. 2012;18:120-222.

26. Korkmaz P, Çevik Çağlan F, Aykın N, Alpay Y, Güldüren HM, Doğru Yaşar Z, et. al. Seroprevalences of HBV, HAV, HCV and HIV infection among health personnel in a state hospital. Klimik Derg 2013;26:64-67.

27. Kurugol Z, Aslan A, Turkoglu E, Koturoglu G. Changing epidemiology of hepatitis A infection in Izmir, Turkey. Vaccine. 2011;29:62596261.

28. Karabulut N. Prevalence of HBV, HCV and HIV in inpatients of a mental health hospital in Turkey, 2011-2013. Iran J Public Health. 2015;44:1026-1028. 